Religious Studies 44, 295-313 ㄷ 2008 Cambridge University Press doi:10.1017/S0034412508009402 Printed in the United Kingdom

\title{
Schleiermacher and Otto on religion: a reappraisal
}

\author{
A. D. SMITH \\ Department of Philosophy, University of Warwick, Coventry, CV47AL
}

\begin{abstract}
An interpretation of the work of Schleiermacher and Otto recently offered by Andrew Dole, according to which these two thinkers differed over the extent to which religion can be explained naturalistically, and over the sense in which the supernatural can be admitted, is examined and refuted. It is argued that there is no difference between the two thinkers on this issue. It is shown that Schleiermacher's claim that a supernatural event is at the same time a natural event does not invite, but rather forecloses the possibility of, a naturalistic explanation of the event. It is further demonstrated that Otto, like Schleiermacher, denied the existence of supernatural events interpreted as events that infringe the laws of nature.
\end{abstract}

In a recent article Andrew Dole has argued that Friedrich Schleiermacher and Rudolf Otto stood for radically different approaches to religion. In particular, they are fundamentally divided over the extent to which religion - more precisely, the religious experiences that they both see as being at the heart of religion - can be investigated and explained naturalistically: explained, that is to say, 'in terms of natural (i.e. non-supernatural) causes' $\left(409\right.$, n. 2). ${ }^{1}$ Otto, according to Dole, wholly rejects the suggestion that religion is amenable to such explanation, whereas Schleiermacher voices appreciation for the attempt so to explain it, and even paves the way for it in his writings. Dole further claims that whereas Schleiermacher's God is 'strictly non-interventionist', in that Schleiermacher entirely rejects the reality of what he terms the 'absolutely supernatural' (that which would involve the infringement or suspension of the laws of nature), Otto embraces such supernaturalism $(410, n$. 31). In this paper I shall argue that there is, in fact, nothing to distinguish between the two thinkers on these issues.

\section{The feeling of absolute dependence}

Although Dole's principal charge is that Schleiermacher welcomed a naturalistic explanation of religion, and it on this that I shall focus in the following 
section, he does voice a related criticism to the effect that Schleiermacher's feeling of absolute dependence, in terms of which he tries to account for religious experience, is too 'thin' to provide a satisfactory account, and that because it fails 'unambiguously to secure reference to a transcendent being suitable for religious veneration', it is too weak to fend off the threat of naturalistic explanation (400-401). Dole attempts to justify his charge of thinness by reference to Schleiermacher's assertion that the feeling of absolute dependence 'accompanies our whole existence' and never occurs in isolation (\$4.3). ${ }^{2}$ Dole interprets this as meaning that the feeling is 'a sort of background component of ordinary experience' (400).

It is true that this feeling is a mere background to ordinary experience if 'ordinary experience' means non-religious experience; but it is most certainly not merely this where religious or 'pious' consciousness is concerned. Piety is not simply a matter of having this background feeling of absolute dependence. If it were, we should all be pious all the time. What is required for piety is, first, that the feeling of absolute dependence-or 'higher self-consciousness', as Schleiermacher also calls it - unite with modes of sensible or 'lower' selfconsciousness to produce a religious 'emotion' (Erregung) (§5.4). ${ }^{3}$ Where there is 'little or no union of it with the various determinations of the sensible selfconsciousness' there is 'little or no religious life’ (\$11.2).

As result of such union the feeling of absolute dependence can vary in strength: 'Of course, it goes without saying in this connection that the feeling of absolute dependence, when it unites with a sensibly determined self-consciousness, and thus becomes an emotion, must vary as regards strength' (\$5.5). It can vary in strength from being there in an 'infinitely small degree' to being there in its 'absolute strength’ (§62.1; cf. §68.2). The latter is to be found only in Christ, whose God-consciousness is characterized by Schleiermacher as being 'absolutely powerful' (\$94.1). What is particularly important for Schleiermacher is the degree to which, as he puts it, the feeling of absolute dependence 'determines the moment' (e.g. §66.1). A person is to be judged religious to the extent that the feeling of absolute dependence dominates his or her conscious life (\$5.3).

There is yet another dimension of variation to the feeling of absolute dependence: one that concerns the extent to which the feeling is clear. True religious experience involves more than the feeling of absolute dependence, even when united with a mode of sensible self-consciousness. It involves, in addition, what Schleiermacher calls 'God-consciousness'. This is attained only when the feeling of absolute dependence is, as Schleiermacher puts it, 'expressed' in an idea (Vorstellung) of God. This idea is 'the most direct reflection upon' the feeling; and the content of the idea is wholly determined by the nature of the feeling. The feeling 'becomes a clear self-consciousness only as this idea comes simultaneously into being' ( $\$ 4.4$; cf. $\S 5$, Postscript). Relatedly, the feeling is clear only to the extent that it is not confused with the mode of sensible self-consciousness 
with which it is united - a mode that itself will, unlike the feeling of absolute dependence, have an immediate reference to some element in the world. Such confusion is to be found, according to Schleiermacher, in idolatry. As a result of such confusion 'even the feeling of absolute dependence is reflected as arising from a particular object to be apprehended by the senses’ (§8.2). Polytheism, too, represents an under-developed state of God-consciousness, since here the feeling of absolute dependence is not appreciated as making the self-same unitary contribution to the variable states of sensible self-consciousness (§8.2). Only when the feeling has been thus distinguished is the term 'God' appropriate to express the feeling. Only then is the feeling properly appreciated and, as it were, fully brought out of the 'background'.

Even if the feeling of absolute dependence, when it is of religious moment, is not 'thin', it does not, according to Dole, secure unambiguous reference to God. Dole makes two points to justify this claim. First, he says that this feeling is not, for Schleiermacher, as it is for Otto, 'the result of an encounter with an object or entity'; he supports this claim by citing Schleiermacher as saying that the feeling 'can in no way proceed from the effect of an object which is somehow to be given to us' (400, citing §4.3). It is, however, quite clear from the rest of the section from which this quotation is taken, and from the following one, that by this statement Schleiermacher means that the feeling is not a response to an object that is 'outwardly given'; and that by this he means given to the senses. In short, it is not given as a worldly, and hence finite, object in relation to which some sense of freedom would be possible. This does not mean that God is not given in religious experience at all. Indeed, Dole himself acknowledges that Schleiermacher states that 'God is given to us in feeling in an original way' (§4.4). Moreover, although Schleiermacher, like many another religious author, does not freely talk about God as an 'object', on occasion he does. The feeling of absolute dependence, he says, 'represents' God; and God is the object (Gegenstand) of this representation ( $\$ 5$, Postscript).

It should not be thought that Otto differs significantly from Schleiermacher on this matter. For Otto, as much as for Schleiermacher, we relate to the divine, or the 'numinous', essentially through feeling (The Idea of the Holy [hereafter $I H$ ], 12-13). ${ }^{4}$ Moreover, numinous experiences 'are themselves not perceptions at all, but peculiar interpretations and valuations' $(I H, 113)$. Although these are 'at first of perceptual data', this occurs at a very primitive and pre-religious stage of human evolution, where the numinous impulse gets 'diverted ... to earthly things, wrongly taken as numinous' $(I H, 125)$. The higher stage that Otto characterizes in terms of 'daemonic awe' constitutes 'a really separate beginning' in the evolution of religious experience $(I H, 122)$. What is significant about this stage is that numinous experience now 'posits' its own proper objects $(I H, 113,125)$. What is essential, in Otto's view, for genuinely religious consciousness is that the numinous faculty 'invents, or, better, discovers, the numinous object by 
rendering explicit the obscure germinal ideas latent in itself' $(I H, 125)$. What, in particular, needs to emerge is the "element of "existent being" [Moment von “Wesen"] ' $(I H, 75)$ : the sense of a presence of a non-natural object that alone can answer to the true inner nature of numinous feeling.

Otto regards religious experience as issuing from the deepest recesses of the human soul, from what he sometimes identifies as the mystics' fundus animae (e.g. $I H, 112)$. From here arise not only distinctive feelings, but also ideas and representations. Here we find 'an a priori basis of ideas and feelings' $(I H, 129)$. When religious awe first stirs, it begins 'to manifest itself in ideas' $(I H, 150, \mathrm{n} .1)$. In the early development of religious consciousness we witness

\footnotetext{
... the obscure basis of meaning and idea [Ideengrundlage] rising into greater clarity and beginning to make itself explicit as the notion [Vorstellung], however vague and fleeting, of a transcendent Something, a real operative entity of a numinous kind, which later, as the development proceeds, assumes concrete form as a 'numen loci', a daemon, an ' $\mathrm{El}$ ', a Baal, or the like. $(I H, 126)$.
}

The numinous, Otto claims, unfolds its full content only by degrees. Only gradually 'does the obscure content [Gehalt] of the feeling, with its reference to absolute transcendent reality, come to light in all its integrity and selfsubsistence' $(I H, 133)$. Otto can even characterize the clear emergence of such meanings in terms of the Platonic concept of anamnesis $(I H, 143)$. Otto therefore stresses the relative insignificance of the actual stimulus to numinous experience. 'Very often', he writes, 'only a very small incitement, a very remote stimulus, is needed to arouse the numinous consciousness' $(I H, 61)$. It is inappropriate, he writes, to speak in such cases of an 'impression' at all, but at most of something serving as 'cue or occasion for the felt experience' $(I H, 125)$.

What is important for Otto is that the proper object of numinous feeling be disengaged from the natural stimulus when there is one. Otherwise there is primitive confusion: the 'wholly other' is confused with, perhaps identified with, some merely natural object - just as in Schleiermacher's account of idolatry. It is precisely to effect such a disengagement that the spirit of man throws up 'posits' to be the proper object of the feeling: daemons, gods, and finally God. Although Otto frequently writes of a sense of the 'presence' of the numinous, his complex analysis of such an experience should not be forgotten. When Dole stresses that, for Otto, numinous experience involves an 'encounter' with a numinous object, he is not wrong; but it may mislead the reader into failing to appreciate the complexity that is involved, for Otto, in such an encounter. In particular, such an encounter is mediated by representations that are thrown up by the human spirit so as to do justice to the inner nature of numinous feelings - just as, for Schleiermacher, the feeling of absolute dependence, when it has so developed that it is clear, receives 'expression' in the idea of God. 
It should also not be forgotten that, although any experience is religious only in as much as it contains the feeling of absolute dependence, this feeling in and of itself gives rise to no religion at all, since there is, in actual human consciousness, no such thing as this feeling 'in and of itself', since that on which one senses oneself to be absolutely dependent is always characterized as having a nature that goes beyond the attributes - such as infinity and transcendence - that are straightforwardly implied by such absoluteness. All religious experience takes the form of religious emotions, which import some such extra content.

The Glaubenslehre continues Schleiermacher's implacable opposition, already voiced in the earlier Speeches, to the idea of 'natural religion'. In religious experience one is never, according to Schleiermacher, simply directed to an infinite ground of all finite reality, but always, on the basis of the particular kind of religious emotion one has, to a divine object of a specific character. In Christian piety, for example, everything is grounded on the experience of the redeeming activity of Christ. Schleiermacher clearly asserts that the sense of divine love that is present in the consciousness of redemption is 'the basis on which all the rest of our God-consciousness is built up’ (\$167.2). The purely monotheistic doctrines elaborated in the first part of the Glaubenslehre were arrived at, Schleiermacher states, on the basis of an abstraction from the rich determinate content of Christian piety. When we abandon the abstraction, and consider actual - for Schleiermacher, specifically Christian - religious consciousness, the language of encounter and presence comes to the fore. Schleiermacher states, for example, that in the consciousness of a person in the grip of conversion, every sense of human intermediation vanishes, and Christ is revealed as immediately present in all His redeeming and atoning activity' (\$108.5). ${ }^{5}$

Dole's final criticism of Schleiermacher in relation to the feeling of absolute dependence is that it is merely 'stipulative' that this feeling relates us to God (401). 'God' is simply defined as the 'whence' of our existence as implied by the feeling. The term stands simply for what Schleiermacher calls the 'codeterminant' of this feeling. The content of the term is, therefore, 'purely formal', and any determinate content is supplied, not by the feeling itself, but from Christian tradition and a specifically Christian form of piety.

Although this is true, such piety, like any form of piety, is, for Schleiermacher, itself possible only because of the presence of the feeling of absolute dependence; and traditional Christian doctrines are taken over by Schleiermacher only to the extent that they can be seen as immediately warranted by such piety. When Schleiermacher works his way through the various divine attributes, he refuses to endorse any that cannot be shown to be implied by the pious 'emotions' that characterize the Christian life. The description of such states of mind is, Schleiermacher claims, 'the fundamental dogmatic form'; and propositions concerning divine attributes are 'permissible' only as they can be 'developed out of' such descriptions (\$30.2). 
So it is not as if, in turning to Christian piety and its (critically sifted) tradition, Schleiermacher is turning to something external so as to eke out his own impoverished account. It is precisely an account of such determinate piety that he is offering. Because of this, some characterizations of God offered by Schleiermacher are grounded on the specifically Christian form of piety. The claim that the essence of God is love, for example, is grounded on the distinctively Christian experience of redemption through Christ (\$167.2). Indeed, it is in the context of this discussion of divine love that Schleiermacher claims that such purely monotheistic attributes as omnipotence are arrived at by 'abstracting' from the determinate richness of Christian piety.

Nevertheless, such abstraction is legitimate. It is not as if Schleiermacher thinks that we are less warranted in ascribing the generically divine attributes to God than we are in ascribing specifically Christian ones. And these attributes are, of course, justified on the basis, specifically, of the feeling of absolute dependence that is the constant and essential ingredient in any pious emotion as such. Although necessarily only an element in a religious emotion, the feeling of absolute dependence itself is hardly 'formal'. It has its determinate character of being absolute. The absoluteness of this feeling 'represents' an absolute infinite, non-worldly, absolutely simple and all-powerful - object. Although God is necessarily more than this, $\mathrm{He}$ is essentially at least this: and that $\mathrm{He}$ is is grounded precisely on the feeling of absolute dependence. Moreover, it is Schleiermacher himself who points out the abstract nature of the feeling of absolute dependence. His whole account of religion is actually based upon specific Christian emotions, which are themselves analysed in terms of the feeling of absolute dependence uniting with modes of sensible self-consciousness that are, considered in themselves, merely secular. These emotions are neither formal nor abstract.

\section{The supernatural in Schleiermacher}

Let us now turn to Dole's principal charge that Schleiermacher envisaged, indeed welcomed, a naturalistic approach to religion. Dole cites (and can cite) only one passage from Schleiermacher in which he even remotely appears explicitly to endorse such a view. It is the following:

We have no desire to keep the leaders of science from scrutinizing and passing judgment from their own point of view upon both piety itself and the communion relating to it, and determining their proper place in the total field of human life; since piety and Church, like other things, are material for scientific knowledge. Indeed, we ourselves are here entering upon such a scrutiny (\$3.1).

This passage will not, however, bear the interpretative weight that Dole assigns to it. That Schleiermacher does not believe that one can outlaw naturalistic scientific investigation into religious phenomena hardly warrants the suggestion 
that he welcomed, or even envisaged the possibility of, such approaches explaining them, or that he was engaged in, as Dole bluntly puts it, 'the enterprise of "explaining religion" itself' (402). For no-one thinks that nothing whatever can truly be said about religion in any respect from a naturalistic standpoint. Is a sociological or a psychological approach to religion misconceived in principle? Such accounts of religion may not be of much interest to a religious person as such, and may wholly fail to come to grips with the true nature or essence of religion. But can they seriously be denied the ability to say anything that is true of religion? Dole clearly supposes Schleiermacher to have been open to the possibility of more than this. And yet it is far from clear that Schleiermacher is suggesting anything more than this in the passage now in question. When Schleiermacher writes that he too is 'entering upon such a scrutiny', I take him to be alluding to the fact that certain of his claims do situate religion in the total field of human life in a way that has no purely religious justification, but rather, as it were, an 'anthropological' one. An example of this would be his assigning religion to 'feeling', or 'immediate self-consciousness', or elsewhere to 'intelligence [Intelligenz] in its subjective function' ( $\$ 4, \S 33.1)$. That Schleiermacher was willing to make such anthropological claims cannot convict him of being open to the possibility of a non-religious 'explanation' of religion.

Locating religious experience in relation to the total field of human life hardly entails explaining it in terms of the rest of human life. If it did, Otto himself would be open to the charge of attempting to explain religion naturalistically, since he too situates religious experience 'anthropologically'. He, like Schleiermacher, sees religious experience as essentially a matter of feeling $(I H, 12-13)$; such feeling gives rise to ideas and valuations that Otto discusses in terms of the Kantian notion of the a priori; and all of this is referred to 'pure reason' and to 'the reasonable spirit of man, with its predispositions, capacities, and its own inherent laws' $(I H, 114)$. All that taking up such an anthropological perspective implies, whether in Otto or in Schleiermacher, is the recognition, hardly to be contested, that religious experience is a human phenomenon in the sense that it is human beings who have such experiences. They can, therefore, be studied in so far as they have such experiences. That Schleiermacher's remarks about the 'leaders of science' implies no more than I have suggested is indicated by an earlier passage in his text, where he states that 'the peculiarity of the Christian Church can neither be comprehended and deduced by purely scientific methods nor be grasped by mere empirical methods' (\$2.2).

Dole's principal case against Schleiermacher, however, concerns the latter's rejection of supernaturalism. Dole is certainly correct that Schleiermacher insistently rejects anything supernatural in one sense of this term. This is the sense that Schleiermacher himself labels the 'absolutely supernatural' (\$13). In this sense the term applies to events in the world; and they are supernatural only if they are contrary to nature. Such an event would involve God's 
abrogation or infringement of the natural workings of the world. We might term this an 'interventionist' conception of a supernatural event. Dole is also correct in claiming that one reason for Schleiermacher's rejection of the absolutely supernatural is his commitment to a view of divine causality as being coextensive with natural causality. Divine causality is fully expressed, according to Schleiermacher, in the creation and preservation of the natural world (403; cf. §51.1). ${ }^{6}$ Schleiermacher does, however, accept the existence of what he on occasion terms the 'relatively supernatural' (\$94.3); and it is this that he means when he uses the term without special explanation.

Dole, by contrast, clearly thinks that the former, interventionist notion is the only 'real' notion of the supernatural. Schleiermacher's introduction of his own notion of the supernatural is, according to Dole, part of his general strategy of palming us off with 'reinterpretations of important terms which retain some of their traditional religious functions, but are incompatible with the denial of divine intervention in the natural order' (407). For Schleiermacher, however, his own supposedly ersatz notion of the supernatural is of fundamental religious significance. He claims, for example, that 'the general idea of a supernatural conception [of Christ] remains ... essential and necessary, if the specific preeminence of the Redeemer is to remain undiminished' (\$97.2). Dole’s account of Schleiermacher's own notion of the supernatural, since it is restricted to making the negative point that it falls short of the supernatural in the absolute sense, and is merely 'contextual' $(406)^{7}$, fails to give the reader any insight into why Schleiermacher should have attached such importance to it. Only by gaining such insight, through attending to Schleiermacher's positive account of his notion of the supernatural, will we be in a position properly to assess Dole's case against Schleiermacher.

If the issue of supernaturalism is to be relevant to Dole's main contention concerning naturalistic explicability, it must be demonstrated that Schleiermacher's rejection of interventionism opens the doors to, or perhaps even embodies, the view that everything (apart, perhaps from the existence of the world as such) is naturalistically explicable. Dole in effect attempts this demonstration in his discussion of Schleiermacher's account of the Incarnation: the supernatural entrance of the divine - or, in Schleiermachian terms, of perfect God-consciousness - into human nature. The Incarnation is, Dole quotes Schleiermacher as saying, a 'natural fact' (406). Dole interprets this and similar passages as indicating that Christ was, for Schleiermacher, 'the result of a natural process or natural processes extended through history’ (406). ${ }^{7}$ If so, His appearance would presumably be amenable to naturalistic explanation.

In fact, although there is, as we shall see, a special sense, for Schleiermacher, in which Christ's appearance in history is the result of a natural process, it is one that does not sustain - indeed, is incompatible with - a naturalistic explanation of that appearance. Conversely, Schleiermacher explicitly denies that 
Christ's appearance is the result of the sort of natural process that would sustain naturalistic explanation of the appearance. Moreover, what applies to Christ will also apply, at one remove, to any religious experiences that essentially depend on Christ's mediation. ${ }^{8}$

Schleiermacher begins his account of the only sort of supernaturalism that he is willing to accept by discussing the emergence of spiritual 'heroes': people with a strikingly new vision, whose emergence marks a new point of development for humanity. Christ is regarded by Schleiermacher as being on a qualitatively different level from such heroes; and yet Schleiermacher denies that even their novelty can be explained: they are 'not explicable by what went before' (§13.1). Although their appearing is 'the result of the power of development which resides in human nature' and is according to 'laws', these laws are, Schleiermacher claims 'hidden from us' (\$13.1). Dole might respond by saying that Schleiermacher believed that such laws could 'in principle' be discovered, and that they would then furnish a naturalistic explanation. I do not believe that this was Schleiermacher's opinion; but we need not concern ourselves with this issue, since, when it comes to the person of Christ, Schleiermacher is categorical. He explicitly denies that perfect God-consciousness in Christ was developed out of human nature (\$97.2). Christ is not, he implies later in the same section, a product of human nature. A little later on he asserts that "no adequate explanation of His origin can be found in an act of the person-forming power of human nature'. He rejects as a 'false peace' the idea that a progressive domination of God-consciousness in man is possible by 'developing simply out of the natural state of man’ (§86.3). Schleiermacher makes similar remarks about the Christian life that fellowship with Christ makes possible: 'It was impossible to attain to this higher life out of the natural order which had its beginning in Adam’ (\$89.1). The reason for this is original sin. Mankind, before Christ, has a 'complete incapacity for good' (\$70). From it 'there could issue no active righteousness properly so called' (\$72.6). Indeed, mankind is 'wholly incapable not only of developing, but even of consciously aspiring to, such inner states as would harmonize with the proper aim and object' of the disposition to God-consciousness (\$70.1). The aim and object of such a disposition is the permanent, perfect, and dominating presence of God-consciousness as we find it in Christ.

After having claimed that the incarnation is a 'natural fact', the first thing that Schleiermacher does by way of explaining what he means is to state that the claim expresses the fact that the entrance of the divine into human nature is a possibility (and 'only' a possibility) for human nature (\$13.1). Later he distinguishes such mere possibility from capacity (Vermögen):

Human nature certainly cannot have been active in being assumed by the divine, in such a way that (to put it so) the being of God in Christ was developed out of the human nature, or even in such a way that there was in the human nature 
a capacity to draw down the divine into itself; only the possibility was innate in

it. ... [T] his possibility is far from being either capacity or activity. (\$97.2)

The admission of such possibility is nothing more than the recognition of the fact that humanity is, in Augustine's words, capax dei. To deny this would be to deny that an incarnation is possible: that God could have become man. It would also be to deny that the process of sanctification is possible for a human being. In the classic phrase, grace perfects nature, it does not destroy it. On several occasions, in order to justify his position on this matter (should it need justifying), Schleiermacher points to the fact that prior to an experience of redemption human beings are conscious of a need for redemption (e.g. §13.2, §94.1). This consciousness points to a lack in non-redeemed humanity. It is only because human nature has not been perfected that such a consciousness of lack is intelligible. The consciousness is precisely the consciousness of a humanity that has fallen short of its true nature.

Since we are dealing with a mere possibility, Christ's existence must involve for human nature 'the actual implanting therein of the divine element'; and this must be 'a purely divine and therefore eternal act' (\$13.1). It takes place, as he says later, 'in virtue of a creative divine causality’ (\$89.2). That the creative divine causality here in question is not simply that which undergirds and is expressed in the general natural processes in the world is made clear when Schleiermacher claims that although the reproductive power of human nature was operative in Christ's conception, a 'creative activity' of God, a 'higher influence' that is 'in addition’ to this was also involved (\$97.2). For 'no person-forming activity of human nature apart from any activity of the divine nature could ever have produced anything but an ordinary human person’ (\$97.2).

The divine activity that is here in question is one that is unique to Christ's appearance, since it is different from the divine activity involved in the birth of any 'ordinary human person'. The appearance of Christ is supernatural for Schleiermacher because it involves a 'special and immediate activity' by God (\$97.2). The beginning of Christ’s life involves 'a new implanting' of Godconsciousness in human nature (\$94.3). The original creation involved 'the impartation of the Spirit to human nature'; the coming of Christ involves a 'second and equally original impartation' (\$94.3). This involves a particular 'accession’ (Hinzutreten) of divine activity (\$97.2). He also writes of an 'entrance' (Eintreten) into mankind of Christ's sinlessness (72.5). Elsewhere, Schleiermacher explicitly contrasts such an entrance into something with an emergence from it: Christ 'must have entered into the corporate life of sinfulness, but He cannot have come out of it' (\$93.3).

Schleiermacher stresses that the corporate life of sinfulness includes the whole human race (\$89.4). This even includes Adam and Eve in their state before the first sin, since 'innate sinfulness was something native also to the first pair' (§72.5). Even they were involved in 'a timeless original sinfulness always and 
everywhere inhering in human nature' (\$72.6). This is important, since it is precisely because humanity as a whole is incapable of perfect God-consciousness, because the propagation of sin is 'natural' for mankind, that Christ's sinlessness can be explained 'only by the universal source of spiritual life in virtue of a creative divine act’ (§93.3, my emphasis).

More, however, is implied by Schleiermacher's claim that the Incarnation is a natural fact than the mere possibility of human nature receiving perfect God-consciousness. Although the 'accession' of the divine in Christ involves a divine act, since divine activity is timeless some account must be given of its appearance in time, in the historical life of Christ. It is this that must, according to Schleiermacher, be regarded as 'an action of human nature, grounded in its original constitution and prepared for by all its past history, and accordingly as the highest development of its spiritual power' (\$13.1). If we do not say this, Schleiermacher argues, we shall have to regard the appearance of the divine act at one time rather than another as a wholly arbitrary matter-something that is unworthy of God. Here, at least, does not Schleiermacher finally reveal his naturalistic inclinations? And this passage is not unique. Perhaps the most challenging such passage is the following:

The origin of every human life may be regarded in a twofold manner, as issuing from the narrow circle of descent and society to which it immediately belongs, and as a fact of human nature in general. ... . [T] he beginning of Jesus' life cannot in any way be explained by the first factor, but only and exclusively by the second ( $\$ 94.3)$.

Here Schleiermacher seems explicitly to say that the incarnation can be explained by reference to human nature in general.

\section{Schleiermacher on human nature}

That more, however, is involved in Schleiermacher's position on this issue than we have yet unearthed is indicated by the fact that we now seem to be faced with a manifest contradiction. On the one hand the birth of Christ is, as we have just seen, 'an action of human nature' (\$13.1); on the other, as we saw earlier, 'no adequate explanation of His origin can be found in an act of the person-forming power of human nature’ (§97.2). The solution to this difficulty is that two notions of human nature are in play in Schleiermacher's account. Moreover, the sort of explanation of Christ in terms of human nature that Schleiermacher grants to be possible is not anything resembling a naturalistic explanation, since the conception of 'human nature in general' that Schleiermacher is employing in this context is not one that is available to a naturalistic explanation. In order to see this, we need to investigate more closely what Schleiermacher means when he characterizes Christ's appearance as an act of human nature.

At one point he characterizes it more fully as 'an original act of human nature' (§94.3). It is the term 'original' that signals the non-naturalistic perspective 
that Schleiermacher is adopting, and in terms of which his reference to explanation is to be interpreted. What this term indicates is that Schleiermacher has in mind his doctrine of Christ as instituting a new creation of mankind or of human nature. As he says in this same section of his text, the beginning of the life of Jesus is 'the completed creation of human nature'. In Him, as he says elsewhere, 'the creation of human nature, which up to this point had existed only in a provisional state, was perfected’ (\$92.1; cf. §94.3). Hence, Schleiermacher can assert that in a sense the creation of man is divided into two stages (\$89.2). The original creation points forward to its completion in Christ and the Christian community of faith: 'The first stage in creation is ordained by God only in view of the second' (§89.3). Indeed, Schleiermacher sees the appearance of Christ as involved in the original creation: 'Although at the first creation of the human race only the imperfect state of human nature was manifested, yet eternally the appearance of the Redeemer was already involved in that’ (§89.3). Since, in God, there is no distinction between resolve and activity, nor between one activity and another, but God is one simple, pure act, there is but one single 'divine decree', which is expressed both in the creation and the incarnation. Schleiermacher can, indeed, go so far as to say that 'Christ even as a human person was ever coming to be simultaneously with the world itself' (§97.2).

The above is the only sense, for Schleiermacher, in which Christ can be seen as an act of human nature, and it is the only sense in which he supposes that Christ's birth can be explained by reference to human nature. It is manifest, however, that none of the above is accessible from a naturalistic point of view. Such a view is restricted to what we can discover about human beings in history, on the basis of their actual condition. The human nature of which Schleiermacher speaks is God's vision of humanity. It is only in this sense that the two stages of creation constitute, as Schleiermacher says they do, 'one and the same natural system'. Precisely because of this, however, it is a natural system that is 'unattainable by us' (\$94.3).

Although he seems not to appreciate its full significance, Dole himself cites a passage from Schleiermacher that makes the same essential point. In it, Schleiermacher states that the connection between the human nature that existed before Christ and the human nature that exists in and as the redeemed result of Christ's life 'is to be found only in the unity of the divine thought' (§88.4). In other words, it is not a naturalistically explicable, or even discernible, connection. The first stage of creation involves, according to Schleiermacher, God putting human nature under the laws of earthly existence (\$89.3). Such a concept of human nature, independent of the laws of earthly existence, is hardly one accessible to naturalistic modes of thought and explanation. The birth of Christ can be seen both as an act of human nature and yet one that can 'be explained ... only by the universal source of spiritual life in virtue of a creative divine act' (\$93.3) because the concept of human nature that is in question is 
discernable only in terms of God's creative activity. One can grasp human nature in this sense only by seeing Christ as 'eternally involved' in its creation (§89.3).

This, again, is clearly not a perspective that is naturalistically attainable. According to Schleiermacher, human nature is 'universally and without exception - apart from redemption - the same' (72.6, my emphasis). The emergence of Christ, uniquely, effects a change in human nature itself. Nevertheless, 'the identity of human nature' is to be found both in redeemed and unredeemed mankind (§88.4). This identity is, however, simply the human receptivity to the divine in virtue of which the 'supernatural can become a natural fact of history'. In other words, it is a receptivity to absolute God-consciousness. But no such receptivity is at all discernible in mankind apart from Christ and the community he establishes as the 'second stage' of creation. It is precisely because this nevertheless constitutes the one true connection between redeemed human nature and human nature as it existed before Christ that Schleiermacher says that such a connection, a connection of 'the identity of human nature in both', is to be found only in the unity of the divine thought. A human being has access to the concept only by having access to this divine perspective: an access that is granted only to those who have experienced the redeeming activity of Christ, since only here is the new creation, and hence true human nature, revealed.

Schleiermacher himself makes it clear that the conception of the 'natural system' that he is invoking, and the potentialities that lie within it, are available only from a religious perspective. The sort of development Schleiermacher discusses in this connection, and the kind of things that are conditions for such development, are, he says, matters of faith (\$61.1). Even the conviction, central to this whole view, that God-consciousness is an essential and highest element in human nature, is one that is given as a result of religious experience (\$60.1). Indeed, religious certainty is required. At one point Schleiermacher considers a person who has religious experiences, 'but unaccompanied by certainty, so that he can equally well regard them as deceptive or veridical’ (\$61.1). Such a person, Schleiermacher states, will not have available the conception of original perfection.

Original perfection is an essential ingredient in Schleiermacher's own conception of human nature and its developmental possibilities. Schleiermacher's whole account of these matters will be a closed book to such a person, and to any naturalistic perspective. And this will also be true, of course, of the religious experience of those who, through faith in Christ, participate in the new creation of humanity established in Christ. That one's nature and experience are transformed by the spiritual presence of Christ is no miracle for Schleiermacher, even when construed in terms of his own notion of the 'relatively' supernatural, since 'every exceptional force attracts mass to itself and holds it fast’ (§88.4). Insofar, however, as the experiences expressive of this inner transformation are 
dependent upon the supernatural presence of the divine in Christ - the 'one great miracle’, as Schleiermacher calls it (\$47.1) - they will be, as such, no more explicable than the emergence of Christ himself. Hence, Schleiermacher writes of them that they 'cannot be explained from what went before' ( $\$ 14$, Postscript). They will be explicable only in the same (non-naturalistic) way as is Christ himself - in terms of the second stage of creation. They, too, will ultimately be explicable, for Schleiermacher, 'only by the universal source of spiritual life in virtue of a creative divine act': in other words, by the single, salvific, creative act that is God Himself.

\section{Otto on supernaturalism}

If it is true, as I have argued, that Schleiermacher no more welcomed, or even conceded the possibility of, a naturalistic explanation of religious experience than did Otto, it is only the issue of the 'absolutely' supernatural that remains as a possible locus of fundamental disagreement between Schleiermacher and Otto. Dole claims to discern a clear difference of opinion here. 'Otto's God intervenes in the natural order', he writes, 'whereas Schleiermacher's God is strictly non-interventionist' $(410, n$. 31). Dole offers no support for this claim that Otto's God is interventionist; and the claim is false.

According to Otto, the world is 'completely governed by law' (Naturalism and Religion [hereafter $N R$ ], 64). ${ }^{9}$ In his view, not only is this compatible with his religiously grounded view of the world, it is required by it: 'The knowledge that man has been produced through a play of highly complex natural processes, fulfilling themselves in absolute obedience to law, in no way prevents our regarding him as a "purpose," as the realisation of a divine idea, in accordance with which nature in its orderliness was planned' $(N R, 81)$. Otto sees religion as requiring a teleological view of the history of the world; and yet 'to a teleological study in this sense the strictly causal interpretations of natural science are not hostile, but indispensable ... . The absolute obedience to law, and the inexorableness of chains of sequences are, instead of being fatal to this position, indispensable to it' ( $N R, 82-83)$. Indeed, the law-governedness of the world is required not only for such a religion-friendly metaphysics, it is, according to Otto, required by religion itself: 'The conception of Nature as obedient to law is not excluded but rather demanded by belief in $\operatorname{God}$ ' $(N R, 35)$. Later, it is 'strict' and even 'absolute' obedience to law that is said to be demanded by faith in God $(N R, 57,83)$. Otto is even willing to pledge allegiance to certain specific fundamental physical laws, such as the conservation of energy $(N R, 232)$. Moreover, this commitment to the absolute law-governedness of the world is not restricted to the purely physical domain. The relation between consciousness and bodily processes is 'in obedience to the strictest law and the most inexorable necessity' $(N R, 301)$. 
What Otto cherishes in religion is its recognition of mystery; and he is clearly opposed to any scientific or speculative programme that would deprive the world of its mystery. Such mystery is, however, not at all imperilled, in Otto's eyes, by the idea of the world as absolutely law-governed. The mystery would remain, he writes, 'even though the attempt to range the whole realm of nature under the sway of inviolable laws were to be immediately successful' $(N R, 44)$. Compare this with Dole's claim that Otto is concerned to offer resistance 'to the possibility of natural explanations of phenomena which "stimulate religious feeling"' (404). It would be surprising indeed if Otto had any such concern, given that he stresses, as we saw earlier, the relative insignificance of the stimulus or occasion for numinous experience. In the present context he justifies his lack of concern by stating that the mystery he is intent on preserving is a mystery that does not force itself into nature as supernatural or miraculous, but is fundamentally implicit in it, a mystery that in its unfolding assuredly follows the strictest law, the most inviolable rules' $(N R, 53)$. Indeed, in Otto's view the study of religion should conform to a scientifically enlightened anti-supernaturalism:

The science of religion searches for the validity of religion and for religion that is valid. It may not return to supernatural standards (for historico-critical reasons and reasons in religion itself); its procedure must therefore be identical with that of moral science, jurisprudence, and all sciences of the mind in general. (The Philosophy of Religion Based on Kant and Fries [hereafter $\left.P R]^{, 222}\right)^{10}$

Otto's anti-supernaturalism is clearly in evidence when he discusses the miracle stories of the New Testament. He refers on one occasion to the charismata of Christ and the early Christians - their power to heal and to foretell the future, and, in general, to exercise 'super-normal physical power'. In considering the claim that any such event really occurred, Otto states that 'our procedure is very uncritical if we propose to rule it out as non-existent simply because it does not square with our current conceptions of "agreement with the natural order" ' $(I H, 208)$. The reason he gives for this, however, is quite different from what one would expect if Dole's interpretation of Otto were correct.

From Dole's perspective, Otto ought to have no problem here: he can in principle accept all such miraculous occurrences as involving a divine suspension of the natural order. What Otto in fact does, however, is to suggest that such things can be accepted because they are, for all we know, compatible with that natural order. If we were to accept the actual occurrence of some such extraordinary phenomenon, we ought to take it 'to be not something "supernatural" and miraculous in the old sense of the word, i.e. something that falls altogether outside all analogies of what happens elsewhere'. He suggests, for example, that prophetic gifts could be elucidated by reference to 'the phenomena of clairvoyance, presentiment, second-sight, \&c.'. And he suggests that it is possible that "the gift of healing of Jesus which appears so puzzling was "merely" a heightened and intense form of capacities which lie dormant in human nature 
in general' $(I H, 208-209)$. This is just the line that Schleiermacher took on this issue ( $\$ 14$, Postscript).

Moreover, there are limits to what Otto can accept. The raising of Lazarus from the dead, the changing of water into wine, walking on water, and so forth are 'excluded from the region of the historically conceivable and admissible' $(I H$, 209). Otto contrasts the raising of Lazarus with that of Jairus's daughter. The latter is perhaps believable, since she, unlike Lazarus, had not lain in the grave for three days, but had lost consciousness for only a short time. 'Where is the margin', asks Otto, 'that divides complete death from the last faint glow of the spark of life, very likely already passed into unconsciousness?' (IH, 209-210). Otto's position is clear: miracle stories are to be accepted as literally true only where it is not unreasonable to think of them as naturally possible. This is, once again, Schleiermacher's attitude.

It is true that Otto rejects a view of nature according to which it is 'thoroughly rationalised and calculable' ( $N R, 54 \mathrm{n})$. What Otto is here rejecting, however, is not the inviolable law-governed nature of the world, but a view of nature as 'translucent and mathematical'. He recognizes 'a vague but deep-rooted antipathy between religion and the mathematical-mechanical conception of things' $(N R, 226)$. The view that Otto sees as opposed to religion is not, as Dole supposes, the refusal to countenance non-natural causes, but something much more extreme: namely, mechanistic reductionism. He is opposed to 'reductions to simpler terms' $(N R, 278)$. 'If nature is not fundamentally simple', he writes, 'then it is not scientific but unscientific to simplify it theoretically' $(N R, 228)$. Otto is especially hostile to the attempt to reduce 'vital phenomena' to mechanical ones $(N R, 227)$.

In case it needs saying, it is clear that Schleiermacher shared this hostility. 'We can never properly understand the beginning of life', he writes (§ 93.3). This is not, for him, a fact about imperfect human comprehension, but is grounded on the facts of the case: 'The impulse which sets the lifeless thing in motion so that it moves other things always comes itself from what is living' (\$49.1). Schleiermacher is especially keen to preserve the integrity of genuine agency: 'If all self-activity in men were determined by the influences of the world it would be merely reaction, and every feeling of freedom, even partial freedom, would be illusory’ (\$59.2). Again, he insists that it would be

... destructive of the feeling of absolute dependence, and with it all piety ... that men should regard themselves too as simply part of this mechanism, and should treat consciousness of self-activity as only an unavoidable illusion. Fortunately, few have ever been capable of this self-annihilating renunciation by which, after robbing the whole world of life, they sacrifice their own selves also to the completeness of their theory. $(\$ 49.1)$

The 'mechanism' to which Schleiermacher here refers-the 'naturemechanism' as he sometimes calls it - is contrasted by him to nature as such, 
or the 'nature-system' (\$34). The former is but one part of the latter. The latter, unlike the former, includes no 'free causes' (\$49). 'None of us', he writes, "understands by "the world" which is the object of divine preservation a naturemechanism alone, but rather the interaction of the nature mechanism and of free agents’ (\$47.1). More generally, Schleiermacher repeatedly appeals to and commits himself to a distinction between 'living' and 'dead' forces, or between the former and 'dead mechanism': between that which does and that which does not essentially involve 'vitality’ (e.g. §51.2). Mere dead causality would be incompatible with the feeling of absolute dependence (\$34.1). 'A lifeless and blind necessity', he writes, 'would not really be something with which we could stand in relation’ (\$55.1). The reductionism that Otto opposed would clearly be one to the 'nature-mechanism'.

The sort of interventionism that Dole attributes to Otto was, in fact, regarded by Otto as 'the source of all danger for the validity of religious conviction' $(P R, 40)$. If the supernatural is seen in opposition to the natural, Otto goes on to say, so that it is a matter of an intervention in the world that infringes or suspends natural laws, then, as our understanding of the workings of the world increases, 'the invisible is forced to take refuge in the cracks and joints in Nature's frame'. In opposition to this Otto pledges his allegiance to a view of the relation between God and world that he associates with Luther, who "cherishes everywhere the conception that God works "through the instrument", i.e. that the whole system of "second causes" is none other than the form of all-powerful divine action, and that it is just in the middle causes that we must look for the working of God' $(P R, 40)$. Schleiermacher could have penned these words.

Perhaps the most ironic thing about Dole's paper is his citing a passage from Otto where he lambasts a certain view as amounting to the 'ossification and materialization of the most tender [element] in religion' (396). ${ }^{11}$ Dole suggests that what Otto is here criticizing are certain 'Humean objections to the very notion of "supernatural" occurrences'. In fact, what Otto is objecting to is supernaturalism and some of its consequences. The sentence preceding the one Dole cites contains the assertion that 'we have no possibility of establishing that an event did not arise from natural causes or was in conflict with the laws of nature'. Since supernaturalism holds that something is miraculous only if it involves an infringement of a law of nature, we can be assured that we are in the presence of a miracle only if we can be certain that it did not arise from natural causes. Otto regards this as a decisive objection to such supernaturalism; and in this he exactly follows Schleiermacher (cf. §47.3). Divination, the faculty of recognizing the holy in its appearances, has, according to Otto, 'nothing whatever to do with natural law and the relation or lack of relation to it of something experienced. It is not concerned at all with the way in which a phenomenon ... came into existence, but with what it means' $(I H, 145)$. The view that Otto 
stigmatizes as an ossification and materialization is precisely the view that Dole would foist on Otto himself.

\section{Conclusion}

Dole's overriding concern is with the question of whether religion can be protected from science and the demand for naturalistic explanation. Otto, he claims, offers a 'powerful protective strategy' against 'empirical or metaphysical challenge to Christianity' (401). Otto is engaged in an attempt 'to ground religion in an area of human life "off-limits" to scientific analysis as a way of warding off naturalistic treatments of religion' (390). By contrast, not only cannot Schleiermacher be 'assigned to the ranks of those primarily concerned with "protecting" religion', he is an 'obstacle' to this (408). If, however, such protection is the goal, then suggesting that supernaturalism in its 'absolute', interventionist sense is essential to religion, as Dole supposes Otto to have believed, is the last way to attain it, as both Otto and Schleiermacher clearly saw.

To suppose that the integrity of religion is dependent upon divine intervention in the world, suspending or infringing the laws of nature, is not to set it 'offlimits' to science, but precisely to put it potentially at odds with science. By involving religion in such issues as the laws of nature, their operation, and possible infringement, it places religion within the sphere of science's competence, and invites its criticism. Indeed, by pinning religion's colours to causal facts, it makes itself answerable to science. The only way to 'protect' religion, if that is an issue, is through Schleiermacher's 'eternal covenant' - as Otto himself clearly saw. ${ }^{12}$

\section{Notes}

1. Simple references such as this are to Andrew Dole's article, 'Schleiermacher and Otto on religion', Religious Studies, 40 (2004), 389-413.

2. References such as this are to Friedrich Schleiermacher The Christian Faith (Edinburgh: T \& T Clark, 1928). This is a translation by H. R. Mackintosh, J. S. Stewart, and others of the 2nd edition of Der Christliche Glaube - a work commonly known as the Glaubenslehre.

3. Sensible self-consciousness is that which accompanies our perception of and interactive relation with things in the world, and which variably involves both a feeling of dependence and of freedom.

4. Rudolf Otto The Idea of the Holy, 2nd edn (Oxford: Oxford University Press, 1950). This is an English translation by John W. Harvey of the 9th German edition of Das Heilige.

5. 'Christus sich ihm ... unmittelbar vergegenwärtigt'. A more literal translation would be that 'Christ presents himself immediately to' the person.

6. Schleiermacher also has various specifically religious objections to interventionist supernaturalism: it supposes God to have been incompetent in creating the world and to be answerable to what occurs in it, and it renders the recognition of the miraculous dependent on a supposition that a law of nature has indeed been infringed - something that cannot be determined with any certainty (\$47.1-3). I should, however, point out that even the metaphysical claim that the domain of divine causality is the same as that of natural causality taken as a whole has a religious foundation for Schleiermacher. The claim is warranted, according to him, by taking the feeling of absolute dependence seriously (\$51.1). 
7. Compare Karl Barth's claim that, according to Schleiermacher, 'the coming of Christ is similar to the formation of a new nebula', in D. Ritschl (ed.) The Theology of Schleiermacher, tr. Geoffrey W. Bromiley (Grand Rapids MI: Eerdmans, 1982), 205.

8. The questions of the supernatural and of naturalistic explicability can be raised in connection with two sorts of events, religious states and experiences, and events in the physical world that are 'miracles' in the usual sense. Dole is primarily interested in the former; and it is on this that I focus in the present section. He also, however, expresses a concern with the second. That will be addressed in the following section.

9. Rudolf Otto Naturalism and Religion (London: Williams \& Norgate and New York NY: G. P. Putnam's Sons, 1907). This is an English translation by J. Arthur and Margaret R. Thomson of Naturalistische und religiöse Weltansicht (Tübingen: J. C. B. Mohr, 1904).

10. Rudolf Otto The Philosophy of Religion Based on Kant and Fries (London: Williams \& Norgate, 1931). This is an English translation by E. B. Dicker of Otto's Kantisch-Fries'sche Religionsphilosophie und ihre Anwendung auf die Theologie (Tübingen: J. C. B. Mohr, 1909).

11. I have quoted Andrew Dole's own translation of the passage. The corresponding passage occurs in Otto The Idea of the Holy, 145.

12. This 'eternal covenant' is referred to, and, to my mind, incomprehensibly criticized and set in opposition to Otto's position, by Dole (390).

\section{CAMBridge JUUANALS}

